VOLUME 33, ARTICLE 1, PAGES 1-30

PUBLISHED 1 JULY 2015

http://www.demographic-research.org/Volumes/Vol33/1/

DOI: 10.4054/DemRes.2015.33.1

Research Article

\title{
Reproductive behavior following evacuation to foster care during World War II
}

\section{Torsten Santavirta}

Mikko Myrskylä

(C) 2015 Torsten Santavirta \& Mikko Myrskylä.

This open-access work is published under the terms of the Creative Commons Attribution NonCommercial License 2.0 Germany, which permits use, reproduction \& distribution in any medium for non-commercial purposes, provided the original author(s) and source are given credit. See http://creativecommons.org/licenses/by-nc/2.0/de/ 


\section{Table of Contents}

$1 \quad$ Introduction $\quad 2$

$\begin{array}{lll}1.1 & \text { Importance } & 4\end{array}$

2 Data and measures $\quad 5$

2.1 Data $\quad 5$

2.2 Measures $\quad 6$

$\begin{array}{lll}2.3 & \text { Descriptive analysis } & 7\end{array}$

3 Estimating the long-term consequences of evacuation on reproductive traits and marriage out$\begin{array}{ll}\text { comes } & 10\end{array}$

$3.1 \quad$ Conditional means comparison: evacuees versus non-evacuees $\quad 10$

3.2 Comparing same-sex siblings with discordant evacuee status 11

$4 \quad$ Discussion $\quad 15$

4.1 Limitations 17

$\begin{array}{lll}4.2 & \text { Conclusions } & 19\end{array}$

$\begin{array}{ll}\text { References } & 21\end{array}$

$\begin{array}{ll}\text { Appendix } & 25\end{array}$ 


\title{
Reproductive behavior following evacuation to foster care during World War II
}

\author{
Torsten Santavirta ${ }^{1}$ \\ Mikko Myrskylä ${ }^{2}$
}

\begin{abstract}
BACKGROUND

Family disruption and separation form parents during childhood may have long-lasting effects on the child. Previous literature documents associations between separation from parents and cognitive ability, educational attainment, and health, but little is known about effects on subsequent reproductive behavior.
\end{abstract}

\section{OBJECTIVE}

We evaluate the associations between unaccompanied evacuation to foster care and subsequent marriage and fertility behavior by comparing Finnish children who were evacuated to Swedish foster families during World War II to their non-evacuated siblings.

\section{METHODS}

In total, some 49,000 children were evacuated for a period ranging from months to years. We analyze a nationally representative sample of 2,009 evacuees born in 1933-1944 by combining data collected from war time government records with 1950 and 1971 censuses and 1971-2011 population registers.

\section{RESULTS}

Comparison of evacuated and nonevacuated same-sex siblings suggests no associations between evacuation and the probability of ever marrying, timing of first birth, and completed family size, although some associations are found in naïve means comparisons. This difference in results across models is suggestive of negative selection of evacuee families.

\section{CONCLUSIONS}

We do not find consistent evidence of any causal effect of family disruption on family formation and reproductive behavior. The results are sensitive to controlling for unobserved

\footnotetext{
${ }^{1}$ Swedish Institute for Social Research, Stockholm University, Sweden. E-Mail: torsten.santavirta@sofi.su.se.

2 Max Planck Institute for Demographic Research, Rostock, Germany. E-Mail: myrskyla@demogr.mpg.de.
} 
Santavirta \& Myrskylä: Reproductive behavior following evacuation to foster care during World War II

selection and suggest that some of the adverse outcomes documented in earlier literature could change if selection was accounted for.

\section{Introduction}

The research during the past few decades on how divorce and bereavement are associated with subsequent life courses has shown strong evidence of compromised early-life transitions (Amato 2010; Kiernan 1992; McLanahan and Bumpass 1988; McLeod 1991). Nevertheless, the consequences of other forms of family disruption for the offspring is an understudied area. From what we already know, it appears to be important for later child outcomes whether family disruption is caused by bereavement, divorce, or parental separation, whether the parents remarry, and whether it is the mother or the father who is absent (Amato 2010; Kiernan 1992; Kendler et al. 2002; Rostila and Saarela 2011). The evidence is however mixed as to which form of parental absence has the most dire consequences and as to which parent's presence plays a more crucial role for the child, the mother's or the father's (Appel et al. 2013; Kiernan 1992; McLanahan and Bumpass 1988; Corak 2001; Lang and Zagorsky 2001).

If the results are mixed concerning parental bereavement and divorce, even less is known about the long-term consequences of temporary separation form parents. This is an important topic, as a large number of children are annually removed from their families either due to abuse and neglect within the family or due to external reasons such as armed conflicts and natural disasters. In the U.S. alone, 400,000 children were estimated to be in foster care in 2012 (AFCARS 2013). In Finland, where our data come from, 11,000 children (approximately 1\% of the total population aged below 16) are in foster care, and the annual number of new placements is approximately 4,000 (National Institute for Health and Welfare 2013). Globally, unaccompanied child refugees tend to account for roughly 2-5 percent of each refugee population, and in 2012, alone more than 21,000 children lodged asylum claims (UNHCR 2012). Even though child displacement in the first mentioned context belongs to the domain of child welfare policy while the latter is conventionally associated with refugee policy, both types of policy share the fundamental feature that the child is removed from his/her parents and placed in foster care for an ex ante unknown period of time with the ultimate goal of reunification with the biological parents.

This paper aims to fill the gap in the literature on temporary parental separation and reproductive behavior by analyzing the long-term outcomes for Finnish children who were evacuated to Sweden during World War II (WWII). Our contribution is twofold. First, we enhance the understanding of the long-term consequences of temporary parental separation, a topic which is of increasing importance, but understudied. Second, we ad- 
dress the problem of unobserved confounding factors by using a within-sibling design. This design substantially mitigates the problem of confounding, which much of the existing research - relying on means comparisons, and adjusting for observed family characteristics - has been unable to resolve.

Our analyses focus on children who were evacuated from Finland to Sweden during WWII, and their siblings. Finland fought two wars against Soviet Union during WWII. During the latter one, which was fought between 1941 and 1944, roughly 49,000 Finnish children from the whole range of socioeconomic backgrounds aged between 1 and 10 years were evacuated to Sweden, and spent on average 2 years in foster families. The evacuations were conducted by a large-scale evacuation scheme with organized logistics on both sides of the border. The Finnish government stated eligibility criteria in 1941 to target the most exposed families. For example, children from displaced households, children at risk from air raids and children whose fathers had died in war were prioritized. The appendix provides more detail on the evacuation policy; in particular, on the historical background, the evacuation from Finland to Sweden, and the placement in foster families in Sweden.

We compare long-term outcomes of evacuees and non-evacuees using unique longitudinal linked data and ask the following question: did family disruption and consequential placement in foster care during WWII have an impact on the individuals' marriage patterns and fertility later in life. Specifically, we look at whether the individual ever married, whether the individual divorced (conditional on having married), number of children, age at first childbirth, and the individual's average interbirth interval. The causal analysis of these questions is nontrivial because of the problem of sorting out the causal effect of evacuation from selection into the evacuation program (Bhrolcháin 2001). Because evacuees were not drawn randomly from the sending population, naïve means comparisons of evacuee and nonevacuee outcomes are likely to be confounded by selection of evacuees. For example, teenage childbearing may have been more common among evacuees than among the nonevacuees because of socioeconomic selection. Girls from working class families - those who are more likely to give birth as teenagers, regardless of evacuation - are overrepresented among the female evacuees. Therefore, in the presence of selection, the mean difference in a naïve means comparison in teenage childbearing between evacuees and nonevacuees will be biased upward.

For this reason, we compare reproductive behavior of evacuees to the reproductive behavior of their same-sex siblings who remained with their biological families throughout the war. The resulting estimate of the association between evacuation and each outcome variable eliminates the between-family component of evacuee selection, as a result of the aforementioned eligibility criteria of the evacuation program, and potentially also other confounding factors related to family background. Furthermore, the within-sibling estimate also eliminates the component of genetic selection shared among siblings.

The data used in the analysis come from a register-based data set consisting of a 
10 percent sample of households drawn from the full 1950 Finnish Census of Population with follow-up of household members in subsequent censuses, beginning at the end of 1970 through 1985 including information on marital status, and data from the Population Register as of 2011 on number of children and their exact birth dates.

We provide the most comprehensive analysis of the impact of foster care on reproductive behavior thus far by using high quality population-based data on sibling discordance for foster care status and reproductive outcomes over the complete fertile age range of the subjects, and marriage patterns until middle-age. Our results suggest robustness in reproductive behavior as we find no evidence of any important differences in reproductive behavior between the evacuated and non-evacuated siblings. However, our naïve adjusted ordinary least squares (OLS) estimates show a significant negative association between evacuation and age at birth of first child for men, and a positive association between evacuation and the probability of divorce for women. These estimates are likely to be biased, as we find a zero association between evacuation and each of the outcomes in the within-sibling analysis. This finding suggests that negative between-family selection into the evacuee program biases the naïve OLS results. According to our preferred within-siblings results, dramatic war time events that led to separation from parents and placement in foster care in a foreign country did on average not leave marks on family formation or fertility patterns. This is an important finding because when considering the costs and benefits of evacuation to foster care, the benefits might include improved probability of surviving, and our results suggest that, at least in terms of marriage market and fertility outcomes, the costs are low.

\subsection{Importance}

Children who face family disruption during childhood are found to do worse along many dimensions than their counterparts who grew up in intact families (Gilman et al. 2003; McLanahan and Sandefur 1994). The studies that attempt to document the effect of family disruption net of socioeconomic background on adult outcomes using a withinsibling design do not tell as consistent a story of socioeconomic selection as one might expect. Björklund and Sundström (2006) did not find any link between divorce and young adults' educational attainment, and on a similar note, Powers (2005) found no association between childhood family structure and the risk of premarital birth among women while holding all sibling-invariant characteristics constant. In contrast, also using withinsibling models, Ermisch and Francesconi (2001) and Gennetian (2005) found, that living in a single-parent household heightened the risk of early childbearing and had a small unfavorable effect on achievement, respectively.

Further, the policy of evacuation to foster care offers a fruitful setting for testing the different hypotheses that life history theory (LHT) has delivered. From a LHT per- 
spective, the examination of associations between reproductive behavior and the largest possible intervention into a child's rearing environment, i.e., the separation from one's biological family and placement in foster care in a foreign country during early childhood, is intriguing. According to LHT, an early life insult to the child's well-being might lead the individual to reproduce early in life so as to maximize the probability of leaving descendants (Belsky 2008). Further, Belsky, Steinberg, and Draper (1991) postulate that childhood adversities are associated with adult personality characteristics that are less well adapted to stable pair-bonding.

Pesonen et al. (2008) find, using a local sample of evacuees from Helsinki $(n=396)$ of the same evacuation program we study, that evacuees had on average earlier menarche, became parents at a younger age (only men), had more children (only women), and shorter interbirth intervals (only men), than other local children of the same age. The existing evidence on the association between childhood adversities and age at menopause is inconclusive. Allsworth et al. (2004) document the fact that abused children had later menopause than controls, whereas Hardy and Kuh (2005) show that children who face family disruptions due to divorce have twice as high a risk of earlier menopause than the control group. The limitation common to all three aforementioned studies is the problem of confounding in the means comparison; that is, the problem of finding a credible comparison group. For example, girls from poorer socioeconomic backgrounds are more likely to give birth as teenagers, regardless of experiencing parental divorce or adoption (Lundberg and Plotnick 1995; Duncan et al. 1998; Kearney and Levine 2014).

\section{Data and measures}

\subsection{Data}

The analysis is based on a ten percent sample of households drawn from the full 1950 Finnish Census of Population (the first full census implemented in Finland). Statistics Finland (2013) drew this sample ${ }^{3}$ (1950 census sample) in 1997 and matched it to the Population Register based on all three first names, last name, and date and place of birth, in order to link the social security number (issued towards the end of the 1960s) of each individual to the data. Thus, the individual had to be alive as of 1970 and reside in Finland in order be included in the matched 1950 census sample that could be linkable to more recent censuses and other register data, based on the social security number. Our sample included individuals from the relevant child evacuee cohorts, born in the period between January 1, 1933, and December 31, 1944, who were sampled into the 1950 census sample $(n=71,788)$. We linked our sample to census records beginning with the

\footnotetext{
${ }^{3}$ The original draw resulted in 411,629 individuals from 114,000 households in 392 municipalities.
} 
1970 census through the 1985 census to extract information on marriage patterns ${ }^{4}$ and to Population Register since 2011 to extract information on the exact birth date of each of the subject's child. The data records both the mother and the father of the child, so information on parenthood is accurate for both. By use of the Finnish National Archive's complete register of all children who were evacuated to foster care in Sweden during World War II, we identified 2,245 individuals as having been evacuated to foster care during World War II within our sample. ${ }^{5}$ We identified all sibling pairs in the sample by use of the family and household identifiers. The family identifier was also used, in combination with a variable for family status, to link the individuals in the sample to their parents and siblings born before study cohorts in order to construct family background covariates. Of the 71,788 individuals in the sample we dropped the individuals whose family identifier was missing $(n=1,136)$ and those who had either died or emigrated before the 1970 census $(n=4,037)$. Our analytic sample consists of 66,615 individuals, of which 2,009 are child evacuees.

\subsection{Measures}

Evacuation (or exposure) is defined as a binary variable obtaining value one if having been evacuated to foster care in Sweden during WW II, according the complete child evacuee register of the Finnish National Archives, and zero otherwise. A caveat to keep in mind throughout the analysis is that by defining exposure this way we are implicitly assuming that siblings remaining with their biological family throughout the war were unaffected by the evacuation of their siblings.

Our outcome variables of interest are: number of children, age at first child birth, average interbirth interval between consecutive two births, having ever married, and being divorced conditional on having been married. Number of children born to the participants by the end of the period of observation in December 2011, age at first childbirth, and interbirth interval (the average interval between all births is calculated only for parents with at least two children), were obtained from the population register. Importantly, our data shows completed fertility, as the individuals were all aged at least 67 by the end of 2011. Marital status was derived from the census records from 1971 through 1985 with 5 -year intervals. We thus observe marital patterns over a 15 year period and are able to construct an indicator variable for whether the individual had ever married by 1985 and

\footnotetext{
${ }^{4}$ We used the variable marital status contained in censuses $1970,1975,1980$, and 1985, to construct the variables Ever married and Divorced (conditional on having been married).

5 The matching procedure of the 1950 census sample to the child evacuee registry of the National Archives of Finland was conducted based on all three first names, last name and exact birth date. It turned out to be surprisingly successful with only 87 ambiguous cases, of which 71 were more likely to be due to errors of spelling (a character missing in the name, one of the first names spelled differently or the birth date varying by 1-2 days while names were matching).
} 
an indicator variable for whether the individual divorced by 1985, conditional on having married before that.

All family background characteristics come from the 1950 census, which (rather fortunately for the authors), contains important questions with the specific purpose to retrospectively survey the family conditions before the outbreak of the war, i.e., as of September 1, 1939. Father's socioeconomic status as of 1939 (SES), replaced by mother's SES if missing, is adjusted for by including class dummies for each class (entrepreneurs as reference category), i.e., white collar workers, blue collar workers, assisting family members, and unemployed or out of labor force. Parental education is adjusted for by including a dummy for whether either the father or the mother had continued their education past primary school. Number of children in the family as of 1939 is calculated based on the birth dates of each child in the family (including those siblings born before 1933, i.e., before the relevant child evacuee cohorts). Native language measures whether the family spoke Swedish or Finnish. Birth order is adjusted for by including an dummy variable for each rank (first born as reference category) and preintervention region of residence is adjusted for by including an dummy variable for county of residence as of September 1, 1939 (the region ceded by the Soviet Union in 1940 (Karelia) is treated as a separate county even though those territories originally belonged to the same county as the part of Karelia that remained on the Finnish side of the border). Duration of evacuation and age at evacuation measured by use of the birth date, date of evacuation and date of return were extracted from the Finnish National Archives.

\subsection{Descriptive analysis}

Table 1 presents the sample characteristics. Panel A shows that the mean differences in outcomes between evacuees and nonevacuees are small with the exception of female evacuees having markedly higher divorce rates than their nonevacuee counterparts $(P<0.001)$. Also, evacuee men showed significantly higher divorce rates than their nonevacuee counterparts $(P=0.01)$. The duration of the average stay in foster care (Panel B) was roughly 22 months for both sexes, and the average age at evacuation was roughly 6.5 years for women and 6.3 years for men.

It is clear from Panel $\mathrm{C}$ that the evacuees and nonevacuees do not balance with respect to family background. The two groups differ in particular with respect to socioeconomic status (e.g., the difference in share of households where the household head is a professional, $P<0.001$, for both genders), number of children in the family $(P<0.001$, for both genders), and native language $(P<0.001$, for both genders). 
Santavirta \& Myrskylä: Reproductive behavior following evacuation to foster care during World War II

Table 1: $\quad$ Sample characteristics of a 10 percent sample of 1933-1944 cohorts from the 1950 Finnish Census of Population (those who survived until 1970 included)

\begin{tabular}{|c|c|c|c|c|}
\hline \multirow[b]{2}{*}{ Characteristic } & \multicolumn{2}{|c|}{ Women } & \multicolumn{2}{|c|}{ Men } \\
\hline & $\begin{array}{c}\text { Evacuees } \\
(n=910)\end{array}$ & $\begin{array}{l}\text { Nonevacuees } \\
(n=31,355)\end{array}$ & $\begin{array}{c}\text { Evacuees } \\
(n=1,099)\end{array}$ & $\begin{array}{c}\text { Nonevacuees } \\
(n=33,251)\end{array}$ \\
\hline \multicolumn{5}{|l|}{ Panel A: Outcomes } \\
\hline Married, percent & $\begin{array}{c}0.92 \\
(0.27)\end{array}$ & $\begin{array}{c}0.91 \\
(0.28)\end{array}$ & $\begin{array}{c}0.92 \\
(0.28)\end{array}$ & $\begin{array}{c}0.90 \\
(0.30)\end{array}$ \\
\hline Divorced, percent & $\begin{array}{c}0.24 \\
(0.43)\end{array}$ & $\begin{array}{c}0.14 \\
(0.35)\end{array}$ & $\begin{array}{c}0.16 \\
(0.37)\end{array}$ & $\begin{array}{c}0.13 \\
(0.34)\end{array}$ \\
\hline Number of children & $\begin{array}{l}1.9 \\
(1.40)\end{array}$ & $\begin{array}{l}1.93 \\
1.39\end{array}$ & $\begin{array}{l}1.86 \\
(1.42)\end{array}$ & $\begin{array}{l}1.78 \\
(1.37)\end{array}$ \\
\hline Age at first birth, years* & $\begin{array}{l}24.08 \\
(4.34)\end{array}$ & $\begin{array}{l}24.32 \\
(4.37)\end{array}$ & $\begin{array}{l}26.19 \\
(4.72)\end{array}$ & $\begin{array}{l}26.70 \\
(4.85)\end{array}$ \\
\hline Mean of child spacing, months ${ }^{\dagger}$ & $\begin{array}{c}48.88 \\
(33.25)\end{array}$ & $\begin{array}{c}48.20 \\
(31.97)\end{array}$ & $\begin{array}{c}51.16 \\
(43.05)\end{array}$ & $\begin{array}{c}50.99 \\
(36.29)\end{array}$ \\
\hline \multicolumn{5}{|l|}{ Panel B: Evacuation program } \\
\hline Duration of evacuation, years & $\begin{array}{c}1.81 \\
(1.12)\end{array}$ & & $\begin{array}{c}1.85 \\
(1.15)\end{array}$ & \\
\hline Age at evacuation, years & $\begin{array}{c}6.49 \\
(2.59)\end{array}$ & & $\begin{array}{c}6.27 \\
(2.54)\end{array}$ & \\
\hline \multicolumn{5}{|l|}{$\begin{array}{l}\text { Panel C: Family background } \\
\text { Socioeconomic status in } 1939\end{array}$} \\
\hline Entrepreneur & $\begin{array}{c}0.11 \\
(0.32)\end{array}$ & $\begin{array}{c}0.27 \\
(0.44)\end{array}$ & $\begin{array}{c}0.11 \\
(0.31)\end{array}$ & $\begin{array}{c}0.27 \\
(0.44)\end{array}$ \\
\hline White collar worker & $\begin{array}{c}0.11 \\
(0.31)\end{array}$ & $\begin{array}{c}0.09 \\
(0.29)\end{array}$ & $\begin{array}{c}0.11 \\
(0.32)\end{array}$ & $\begin{array}{c}0.10 \\
(0.29)\end{array}$ \\
\hline Blue collar worker & $\begin{array}{c}0.44 \\
(0.50)\end{array}$ & $\begin{array}{c}0.30 \\
(0.46)\end{array}$ & $\begin{array}{c}0.42 \\
(0.49)\end{array}$ & $\begin{array}{c}0.30 \\
(0.46)\end{array}$ \\
\hline Assisting family member & $\begin{array}{c}0.03 \\
(0.16)\end{array}$ & $\begin{array}{c}0.08 \\
(0.27)\end{array}$ & $\begin{array}{c}0.03 \\
(0.18)\end{array}$ & $\begin{array}{c}0.08 \\
(0.27)\end{array}$ \\
\hline Unemployed or out of Labor force & $\begin{array}{c}0.31 \\
(0.46)\end{array}$ & $\begin{array}{c}0.26 \\
(0.44)\end{array}$ & $\begin{array}{c}0.33 \\
(0.47)\end{array}$ & $\begin{array}{c}0.25 \\
(0.44)\end{array}$ \\
\hline Parental education & $\begin{array}{c}0.07 \\
(0.26)\end{array}$ & $\begin{array}{c}0.07 \\
(0.25)\end{array}$ & $\begin{array}{c}0.09 \\
(0.29)\end{array}$ & $\begin{array}{c}0.07 \\
(0.26)\end{array}$ \\
\hline Number of children in 1940 & $\begin{array}{c}2.23 \\
(1.44)\end{array}$ & $\begin{array}{c}1.58 \\
(1.67)\end{array}$ & $\begin{array}{l}2.29 \\
1.52)\end{array}$ & $\begin{array}{c}1.62 \\
(1.69)\end{array}$ \\
\hline Swedish speaking & $\begin{array}{c}0.14 \\
(0.35)\end{array}$ & $\begin{array}{c}0.06 \\
(0.23)\end{array}$ & $\begin{array}{c}0.14 \\
(0.34)\end{array}$ & $\begin{array}{c}0.06 \\
(0.24)\end{array}$ \\
\hline
\end{tabular}

Notes: The standard errors of the sample means are reported in parentheses. The socioeconomic status of the family in 1939 is based on father's occupation, replaced, if missing, by mother's occupation. Parental education measures the highest level of schooling of either the mother or the father with an indicator variable obtaining one if either parent attained education past primary school. *Sample size for Age at first birth is 27,074 for men and 26,984 for women. ${ }^{\dagger}$ Sample size for Mean of child spacing is 20,568 for men and 20,273 for women. 
Additional evidence for evacuee selection is provided by regressing an indicator variable for evacuee status of the household against family background characteristics. Table 2 shows evidence of selection of evacuee households. In evacuee households with more than one sibling, the parent with the higher education was 1.9 percentage points (24\%) less likely to continue schooling past primary school. Further, evacuee household heads were 6.9 percentage points (111 percent) more likely to be native Swedish speaking and the household head was 5.2 percentage points (18 percent) more likely to hold a blue collar occupation as compared to their counterparts of non-evacuee households.

Table 2: $\quad$ Evidence on evacuee selection: Regressing an indicator variable for whether evacuees in household (HH) (1 if yes) on family background characteristics

\begin{tabular}{|c|c|c|c|c|}
\hline & \multicolumn{2}{|c|}{ All households } & \multicolumn{2}{|c|}{ HH with $>1$ siblings } \\
\hline & $\begin{array}{c}\text { Control } \\
\text { mean }\end{array}$ & $\begin{array}{l}\text { Dependent variable: } \\
\text { Evacuee status of } \mathrm{HH}\end{array}$ & $\begin{array}{c}\text { Control } \\
\text { mean }\end{array}$ & $\begin{array}{l}\text { Dependent variable: } \\
\text { Evacuee status of } \mathrm{HH}\end{array}$ \\
\hline $\begin{array}{l}\text { Parental education, } \\
\text { (past primary } \\
\text { school=1) }\end{array}$ & 0.078 & $\begin{array}{r}-0.015 \\
(0.004)\end{array}$ & 0.078 & $\begin{array}{r}-0.019 \\
(0.007)\end{array}$ \\
\hline $\begin{array}{l}\text { Number of children } \\
\text { in the family in } 1940\end{array}$ & 1.31 & $\begin{array}{c}0.017 \\
(<0.001)\end{array}$ & 1.73 & $\begin{array}{c}0.014 \\
(0.001)\end{array}$ \\
\hline Swedish speaking & 0.069 & $\begin{array}{c}0.046 \\
(0.005)\end{array}$ & 0.062 & $\begin{array}{l}0.069 \\
(0.009)\end{array}$ \\
\hline $\begin{array}{l}\text { Occupation, (blue } \\
\text { collar worker=1) }\end{array}$ & 0.308 & $\begin{array}{c}0.038 \\
(0.003)\end{array}$ & 0.294 & $\begin{array}{c}0.052 \\
(0.004)\end{array}$ \\
\hline Observations & 37,193 & 38,765 & 17,993 & 19,027 \\
\hline
\end{tabular}

Notes: Sample means of background characteristics for the control group of households $(\mathrm{HH})$ without any evecuees and OLS estimates for all $\mathrm{HH}$ are reported with robust standard errors of the OLS estimates in parentheses.

Table 3 shows that, among women, no clear relationship between age at evacuation and reproductive behavior exists, although the few mothers who as children were evacuated before age $2(n=18)$ had a clearly deviant reproductive behavior as compared to the other age groups, with more teenage childbearing and lower number of in total during the reproductive career. 
Santavirta \& Myrskylä: Reproductive behavior following evacuation to foster care during World War II

Table 3: $\quad$ The average number of children and age at first childbirth of mothers who as children were evacuated - split by age at evacuation

\begin{tabular}{lccccc}
\hline & $\begin{array}{c}\text { Non-separated } \\
\text { siblings } \\
(n=418)\end{array}$ & $\begin{array}{c}<2 \text { yrs } \\
(n=18)\end{array}$ & $\begin{array}{c}2 \text { to }<4 \text { yrs } \\
(n=141)\end{array}$ & $\begin{array}{c}4 \text { to }<7 \text { yrs } \\
(n=243)\end{array}$ & $\begin{array}{c}7 \text { to } 11 \text { yrs } \\
(n=358)\end{array}$ \\
\hline $\begin{array}{l}\text { Number of children } \\
\begin{array}{l}\text { Age at first } \\
\text { childbirth }\end{array}\end{array}$ & $2.30(1.22)$ & $1.78(0.73)$ & $2.10(1.15)$ & $2.22(1.09)$ & $2.39(1.34)$ \\
\hline
\end{tabular}

Notes: For comparison, both outcomes are reported for mothers, i.e., number of children refers to the average number of children among women who had at least one child. The average number of children for all mothers in the sample $(n=26,984)$, was 2.30 and the average age at first childbirth was 24.30. Standard deviations are reported in parentheses.

\section{Estimating the long-term consequences of evacuation on reproductive traits and marriage outcomes}

\subsection{Conditional means comparison: evacuees versus non-evacuees}

Our first approach to exploring the long-term consequences of evacuation is to compare the outcomes of interest of all evacuees to all nonevacuees while conditioning on important potential confounders. We estimate the following model,

$$
Y_{i}=\beta_{0}+\alpha\left(\text { Evacuee }_{i}\right)+\left(\text { Family background }_{i}\right) \beta_{1}+\delta_{\text {county }}+\theta_{\text {birth cohort }}+\varepsilon_{i},
$$

where outcome $Y$ for child $i$ is explained by a binary variable, Evacuee ${ }_{i}$, equal to one if individual $i$ was evacuated to Sweden during World War II and placed in foster care and with a vector of observable family background covariates (each variable shown in Panel $\mathrm{C}$ in Table 1 included). County fixed effects are used so as to compare individuals living in the same county as of 1940, i.e., before the intervention, and birth cohort indicators are used to capture changes in reproductive behavior over time. We use the same model specification for all our five different outcomes (see Panel A in Table 1) and estimate the difference in means between evacuees and non-evacuees using OLS. For our two binary outcomes, ever married and divorced, the OLS translates into a linear probability model. Results are similar when a probit model is used, as shown in Table A1 of the appendix. The standard errors are clustered at the family level in all estimations, to reflect variation in the propensity to evacuate across families.

We estimate equation (1) separately for the male and female subsample, allowing all of the covariates to have different coefficients depending on sex, rather than constraining all differences between sexes to work through the variable of interest $\left(\right.$ Evacuee $\left._{i}\right)$, which would be the case, if only an interaction term between sex and evacuation was included. 
The first row of Table 4 shows that, for women, a significant association is found between evacuation and the probability of divorcing; women who were evacuated to foster care during WWII had an 8.5 percentage points higher probability of having divorced conditional on being married than their non-evacuee counterparts. The coefficients of parental education and the indicator for whether parents were blue collar workers are significant in three regressions out of five, whereas native language and number of children in the family in 1940 only played a role for the age at first childbirth. Table 5 presents the same results for men. Evacuated men had their first child on average roughly 5 months earlier than their nonevacuated counterparts. The coefficient of number of children is marginally significant but not substantively meaningful; the evacuated men have an average of 0.08 units larger families than their nonevacuated counterparts.

\subsection{Comparing same-sex siblings with discordant evacuee status}

If the Finnish policy of evacuating children to foster care was indeed a natural experiment, i.e., the evacuees were randomly drawn from the Finnish population of prewar cohorts of children, then $\alpha$ in equation (1), which is the coefficient reported in the first row of Tables 4 and 5, would be the true causal effect of participation in the evacuation program. However, both anecdotal evidence on the eligibility criteria to the program and empirical evidence (descriptive statistics presented in this study and Santavirta and Santavirta 2014) suggest that evacuees came from more adverse family backgrounds. Thus, the largest concern when evaluating the long-term consequences of this early life intervention is that the associations found are contaminated by confounding bias: children's family background could affect both the likelihood of being evacuated as well as adult outcomes.

Fixed effects can be a powerful way to eliminate confounding factors from shared family background characteristics, even when they are not fully observed. In most families who participated in the program, only some of the children were sent away. Comparing outcomes of siblings eliminates confounding bias induced by shared aspects of the family background that are correlated with both evacuation and reproductive behavior/marriage patterns. Obvious potential confounding factors that may plague the naïve OLS analysis are, e.g., parental death and other eligibility criteria (see the historical background described in the appendix), parental child-rearing skills, and parental depression. In addition to the shared family environment among siblings, shared genetic factors (approximately 50 percent), are also held constant using a within-sibling design. 
Santavirta \& Myrskylä: Reproductive behavior following evacuation to foster care during World War II

Table 4: $\quad$ Associations between the evacuation to foster care during World War II and subsequent marriage patterns and reproductive traits women

\begin{tabular}{lccccc}
\hline & $\begin{array}{c}\text { Ever } \\
\text { married }\end{array}$ & Divorced & $\begin{array}{c}\text { Number } \\
\text { of children }\end{array}$ & $\begin{array}{c}\text { Age at first } \\
\text { childbirth }\end{array}$ & $\begin{array}{c}\text { Inter-birth } \\
\text { interval }\end{array}$ \\
\hline Evacuated & 0.010 & $0.085^{* * *}$ & -0.004 & -76.769 & 47.650 \\
& $(0.009)$ & $(0.016)$ & $(0.049)$ & $(60.405)$ & $(43.972)$ \\
Parental education, & & & & & \\
(Past primary school=1) & -0.008 & $0.035^{* * *}$ & $-0.087^{* * *}$ & $481.155^{* * *}$ & -33.115 \\
& $(0.008)$ & $(0.011)$ & $(0.032)$ & $(48.510)$ & $(36.397)$ \\
SES in 1939 & & & & & \\
$\quad$ White collar & $<0.001$ & 0.051 & -0.057 & 205.875 & -109.653 \\
& $(0.030)$ & $(0.047)$ & $(0.112)$ & $(162.600)$ & $(96.435)$ \\
Blue collar & $0.019^{* * *}$ & $0.046^{* * *}$ & -0.009 & $-269.586^{* * *}$ & 23.181 \\
& $(0.005)$ & $(0.006)$ & $(0.022)$ & $(28.013)$ & $(18.861)$ \\
Assisting family & $<-0.001$ & 0.004 & -0.023 & -26.942 & 11.825 \\
$\quad$ member & $(0.007)$ & $(0.008)$ & $(0.034)$ & $(42.422)$ & $(27.744)$ \\
Unemployed or out of & $0.010^{* *}$ & 0.042 & 0.029 & $-263.315^{* * *}$ & -23.313 \\
labor force & $(0.005)$ & $(0.006)$ & $(0.023)$ & $(28.651)$ & $(18.736)$ \\
Native language, & 0.025 & -0.032 & -0.142 & $105.685^{* *}$ & -2.894 \\
$\quad$ Swedish=1) & 0.008 & $(0.012)$ & $(0.036)$ & $(50.511)$ & $(36.609)$ \\
Number of children in & & & & & \\
the family in 1940 & -0.003 & -0.001 & 0.024 & $26.897^{* *}$ & -5.048 \\
& $(0.002)$ & $(0.002)$ & $(0.010)$ & $(11.299)$ & $(8.042)$ \\
& & & & & \\
Observations & 32,265 & 29,407 & 32,265 & 26,984 & 20,273 \\
\hline
\end{tabular}

Notes: OLS estimates for evacuee status. Standard errors (in parentheses) are clustered at family level. All specifications also include 12 categorical variables for birth order, 20 categorical variables for residence municipality in 1939 and 11 categorical variables for birth cohort. Age at first childbirth and inter-birth interval are measured in days. 
Table 5: $\quad$ Associations between the evacuation to foster care during World War II and marriage patterns and subsequent reproductive traits men

\begin{tabular}{lccccc}
\hline & $\begin{array}{c}\text { Ever } \\
\text { married }\end{array}$ & Divorced & $\begin{array}{c}\text { Number } \\
\text { of children }\end{array}$ & $\begin{array}{c}\text { Age at first } \\
\text { childbirth }\end{array}$ & $\begin{array}{c}\text { Interbirth } \\
\text { interval }\end{array}$ \\
\hline Evacuated & 0.003 & 0.006 & $0.080^{*}$ & $-146.72^{* * *}$ & 49.02 \\
& $(0.009)$ & $(0.013)$ & $(0.045)$ & $(44.31)$ & $(51.87)$ \\
Parental education, & & & & & \\
(Past primary school=1) & $0.023^{* * *}$ & 0.005 & $0.075^{* *}$ & $302.42^{* * *}$ & 0.83 \\
& $(0.006)$ & $(0.009)$ & $(0.030)$ & $(46.06)$ & $(34.52)$ \\
SES in 1939 & & & & & \\
White collar & $0.046^{* *}$ & 0.044 & 0.113 & -191.92 & -85.98 \\
& $(0.023)$ & $(0.040)$ & $(0.128)$ & $(193.93)$ & $(102.17)$ \\
Blue collar & $0.028^{* * *}$ & $0.051^{* * *}$ & $-0.062^{* * *}$ & $-375.40^{* * *}$ & $76.48^{* * *}$ \\
& $(0.005)$ & $(0.006)$ & $(0.022)$ & $(30.62)$ & $(21.01)$ \\
Assisting family & -0.012 & -0.003 & -0.028 & -2.51 & -23.67 \\
member & $(0.008)$ & $(0.007)$ & $(0.034)$ & $(47.70)$ & $(28.81)$ \\
Unemployed or out of & $0.022^{* * *}$ & $0.043^{* * *}$ & $-0.072^{* * *}$ & $-269.14^{* * *}$ & 31.85 \\
labor force & $(0.005)$ & $(0.006)$ & $(0.023)$ & $(31.42)$ & $(20.90)$ \\
Native language, & 0.003 & $-0.038^{* * *}$ & $-0.155^{* * *}$ & $244.68^{* * *}$ & -12.97 \\
(Swedish=1) & $(0.008)$ & $(0.011)$ & $(0.028)$ & $(58.79)$ & $(43.07)$ \\
Number of children in & & & & & \\
the family in 1940 & $-0.007^{* * *}$ & 0.002 & -0.006 & $46.71^{* * *}$ & 4.64 \\
& $(0.002)$ & $(0.002)$ & $(0.009)$ & $(12.59)$ & $(8.86)$ \\
Observations & 34,350 & 30,840 & 34,350 & 27,074 & 20,568 \\
\hline
\end{tabular}

Notes: OLS estimates for evacuee status. Standard errors (in parentheses) are clustered at family level. All specifications also include 12 categorical variables for birth order, 20 categorical variables for residence municipality in 1939 and 11 categorical variables for birth cohort. Age at first childbirth and interbirth interval are measured in days.

We consider the following equation in which the individual error term is decomposed into two components, $\eta_{j}$, and, $\nu_{i j}$ :

$$
\begin{aligned}
Y_{i j}=\beta_{0}^{\mathrm{ws}}+\alpha^{\mathrm{ws}}\left(\text { Evacuee }_{i j}\right)+\left(\text { Family background }_{i j}\right) \beta_{1}^{\mathrm{ws}}+ \\
\delta_{\text {county }}^{\mathrm{ws}}+\theta_{\text {birth cohort }}^{\mathrm{ws}}+\eta_{j}+\nu_{i j},
\end{aligned}
$$

where $\eta_{j}$ is the component of the error term shared between full siblings living in the same household $j$ and $\nu_{i j}$ is the idiosyncratic component specific to each individual.

Table 6 reports the same-sex within-sibling estimates for subsamples with sibling groups of at least two same-sexed siblings. For comparison the naïve OLS estimates using equation (1) are also reported. The statistically and substantively significant association between evacuation and divorce for women obtained by OLS becomes statistically indistinguishable from zero in the within-sibling comparison. Likewise for men, the association between evacuation and age at first childbirth in the OLS turns into a zero 
association in the within-sibling analysis. We exploit all permutations of sibling pairs in each household. However, a caveat to keep in mind when interpreting the within-sibling results is that evacuees who were singletons $(n=538)$ and sibling pairs of which both were evacuated do not contribute to the identification of $\alpha$ (Table A2 in the appendix breaks the sibling pairs into pairs of nonevacuees, pairs discordant for evacuee status and pairs in which both siblings were evacuated). A Hausman test is preformed and reported in Table 6 for each outcome variable, to determine whether OLS is sufficient or whether a within-sibling model is needed (Cameron and Miller 2015). ${ }^{6}$ If OLS were consistent it would be preferable, since all the between-family variation in the variables is lost in the within-sibling estimation and sibling-invariant regressors are not identified.

By comparing our naïve OLS estimates of the associations between evacuation and our outcomes $(\alpha)$ and the within-sibling estimate $\left(\alpha^{\text {ws }}\right)$ we can sign the direction of the unobserved household-specific confounding elements that operate net of observed family characteristics such as parental education and occupation. As for the divorce estimates for women, $\alpha^{\mathrm{ws}}<\alpha$ suggests that $\alpha$ is biased by negative selection of evacuee families, i.e., evacuees differ on average in their outcomes from their nonevacuee counterparts from the same county and cohort due to more adverse family environment as opposed to any effect of evacuation itself. On a similar note, we also find evidence of negative selection bias in the age at first child birth estimates for men $\left(\alpha^{\text {ws }}>\alpha\right)$. Men who were evacuated as children do not exhibit any difference in reproductive behavior when compared with their same-sex nonevacuee siblings. Taken overall, our within-sibling estimates provide evidence of a zero association between evacuation and family formation, probability of divorce, and reproductive behavior, and that the adverse associations obtained by naïve OLS are contaminated by negative confounding bias.

\footnotetext{
${ }^{6}$ We use a cluster-robust version of the Hausman test proposed by Wooldridge (2010, p. 332) implemented in Stata 13 using xtoverid by Schaffer and Stillman (2010).
} 


\section{Discussion}

We analyzed the long-term impact of being evacuated to foster care in war time on the individuals' marriage patterns, risk of divorce, and fertility later in life. Prior research on both the same Finnish evacuation program that we analyzed (Pesonen et al. 2008), as well as other studies on family separation, tends to find important negative associations between family separation and later life outcomes (Kiernan 1992; McLanahan and Bumpass 1988; McLeod 1991). An important question regarding these findings is to what extent they represent causal effects. Our naïve OLS regressions that do not account for unobserved confounding elements are consistent with prior research; for example, evacuated women appear to have an elevated risk of divorce. However, in analyses in which we compare evacuated siblings to their non-evacuated peers, effectively controlling for all unobserved factors shared by the siblings and in particular family background, the picture changes. For each of the family formation and fertility outcomes that we analyze, the within-sibling estimates suggest no differences between the evacuated and non-evacuated.

Our analysis was based on large, nationally representative, longitudinal data that possess many features that make them particularly well suited for evaluation of long-term outcomes of the Finnish child evacuee policy. First, linking social security numbers to a random sample of the 1950 census allows for unusually long follow-up periods of the subjects - for example, we are able to analyze completed fertility - while at the same time avoiding the problem of potential recall bias that arises when childhood characteristics are retrospectively retrieved. Second, the availability of a family identifier and a variable defining the family ties between each family member in the 1950 census makes the data suited for within-sibling analysis, while also providing family background variables dating back to the period before WWII for the naïve adjusted means comparisons. Third, additional leverage is gained by linking this existing census sample with individual-level war time data from a child evacuee registry.

Our results provide important new information about the potential effects of temporary parental separation and also about the determinants of family formation and fertility. Parental separation is a dramatic experience for a child and clearly the costs and gains in each setting need to be evaluated before formulating policy. In settings such as ours in which the evacuation was a war-time policy, the potential gains are quite clear, as the goal is to increase the survival probability of the children. Our results suggest that at least in terms of family formation and fertility, the evacuees had similar later-life outcomes to non-evacuees, implying that the costs of the evacuation borne by the children may have been smaller than expected. Importantly, these key results are obtained with an innovative within-sibling design while naïve OLS regressions do suggest adverse outcomes for the evacuees. Prior research that in both similar and different settings evaluates the impact of family disruption often finds negative associations for a large range of later life outcomes, but often does not consider unobserved heterogeneity (e.g., McLanahan 
and Bumpass 1988; McLeod 1991; Pesonen et al. 2008). It is possible that some of the adverse findings would change if unobserved heterogeneity was accounted for.

The results also suggest remarkable robustness in family formation and fertility behavior, as a dramatic event that took children from their families and placed them in a new country and new family left no marks on subsequent family formation or fertility. Some theories, in particular the life history theory, postulate that early life experiences might influence subsequent family formation and fertility because they change the (real of anticipated) expected survival probabilities and might create incentives to reproduce early. We find no evidence of changing reproductive behavior in response to being evacuated to foster care. On the other hand, the attachment theory suggests that adverse early life experiences might negatively influence subsequent family formation (Bowlby 1980). Again, we find no evidence of this. It is possible that these mechanisms are weak or not operating at all, or perhaps slightly more unlikely, are both operating but cancel each other.

The question of external validity, and to what extent the findings of the long-term effects of the Finnish evacuation policy during WWII generalize to other forms of family disruption is highly pertinent to this study. Even though the predictive value of our results may not extend directly to settings other than large-scale evacuation programs, lessons can be learned from comparisons of our results to the results of studies on family disruption and foster care placements induced by familial processes. In particular, they enhance our understanding of separation from parents by providing robust evidence of an understudied type of separation from parents, i.e., separation due to an exernal shock. When making comparisons to other types of bereavement and separation, an important aspect to keep in mind is that the comparison group was often separated from their fathers for long periods of time due to the war. Our findings are likely to be most relevant to the discussion of the impact of war time displacement in general, and contemporary refugee experiences with which the Finnish experience has both similarities and differences. One key difference between the Finnish evacuation policy and current situations in which child refugees are considered unaccompanied is that today's children are often unattended by an adult on their journey from their biological families to foster care (International Committee of the Red Cross: Central Tracing Agency and Protection Division 2004). A significant difference as compared to contemporary foster care policy due to internal factors is that the majority of the evacuated Finnish children spoke only Finnish, and when placed in Swedish families, had to cope with a new language. This presumably made the experience more difficult. Also, many contemporary foster care placements are made to kinship care (roughly 30 percent in the U.S.) whereas this was not the case in the Finnish evacuation policy (AFCARS 2013). However, the average time spent with Swedish foster families (22 months) is strikingly similar to contemporary foster care placements. In the U.S. the average time in care for children exiting foster care was 20.4 months in 2012 (AFCARS 2013). Thus, there are both similarities and 
differences, and among the differences we identify in particular factors suggesting that the historical evacuation of Finnish children may have been more stressful compared to the more recent foster care programs.

\subsection{Limitations}

Even though the data used in the analysis is of exceptional quality and geared towards the examination of our research question, and the within-sibling design accounts for many shortcomings that are present in comparisons between-families, also these data and design have limitations.

First, our within-sibling analysis is adjusting solely for sibling-invariant aspects of the family background. Thus, the identifying assumption for a causal interpretation of our within-sibling estimate is that exposure, in this case the parental decision to evacuate a specific sibling, was uncorrelated with unobserved sibling-specific characteristics (Rosenzweig and Wolpin 1995). This is a strong assumption, as the literature documents a range of differences between siblings in a family context that could potentially bias our evacuation estimate. We reduce the amount of unadjusted, child-specific, potential confounding effects by adjusting for the following sibling-specific factors: age and birth order. Birth order is a potential confounder in almost any between-sibling research designs dealing with interventions during early life and later-life health, as it has been found to be inversely correlated with education and cognitive ability, and suicide (Black, Devereux, and Salvanes 2005; McCall 1977; Rostila, Saarela, and Kawachi 2014).

Second, it is possible that parents might, after reunification, try to adjust parental investments across siblings so as to compensate for the experience of parental separation or experience of war (whichever was perceived to be more stressful). The literature on postnatal parental investments shows mixed evidence of parental responses; Del Bono, Ermisch, and Francesconi (2012) find evidence in favor of compensating strategies while Bharadwaj, Løken, and Neilson (2013) find no such evidence.

A related concern is that the siblings left behind, who stayed with their biological parents throughout the war may have been affected by the separation from their siblings. If this type of separation had a similar influence on fertility behavior as the evacuation effect did, then the evacuation estimates would be biased towards zero. This scenario might explain some of our null findings. In addition, it is plausible that the behavior of the evacuated sibling may influence the behavior of the left-behind sibling, or vice versa. Past research suggests that siblings influence each other's childbearing patterns, although the effects are not very large, particularly in models for births after the first child (Lyngstad and Prskawetz 2010). Nevertheless, such influences would mean that in a within-sibling design, the potentially existing effects of the evacuation on subsequent childbearing are underestimated. It would, in principle, be possible to analyze the role of 
this mitigating effect by stratifying the analysis based on factors that might reflect how likely it is that siblings do or do not influence each other - for example, proximity defined by age or region of residence might be viable stratifying factors - however, our data is not very large to begin with, and such analyses would further reduce our power to detect a signal.

Third, there is attrition between 1950 and 1970 between which years the individuals are not observed. A small proportion of these subjects had died but a more important source of attrition was the mass migration to Sweden in the late 1960s. Table 7 compares those lost before 1971 to the analytic sample. The subjects lost were less likely to be women, more likely to be evacuated and to speak Swedish as their native language, although there were small differences in socioeconomic background and parental education. We cannot however exclude the possibility that attrition may bias the results; attrited individuals may have systematically differed with respect to exposure or outcomes from the individuals included in the analytic sample. If for instance individuals who died or emigrated before 1971 were more likely to participate in the evacuation policy and at the same time more likely to give birth at an early age then we would have observed larger associations between evacuation and early childbearing for the base population.

Fourth, within-sibling analysis estimates tend to be more attenuated than OLS estimates as they are more susceptible to measurement error in the exposure variable (Bound and Solon 1999). As for the evacuation parameter this should be less of a concern, as the complete child evacuee registry was matched to the census sample based on all three first names, last name and date of birth. Only 87 ambiguous matches were found while linking the entire war-time registry, including 48,628 child evacuees to the 71,788 individuals of the 1950 census sample. Among these, 71 cases were such that the mismatch seemed to indicate a spelling error (e.g., in the (manual) spelling of one of the three first names or the month being January (1) in one of the registries and July (7) in the other while complete name, day, and year matched). These cases were kept in the analysis but dropping all 87 ambiguous observations did not change the results qualitatively. Despite our relatively high confidence in having correctly identified those who were evacuated and those who were not, it is possible that our operationalization of the evacuation variable influences some of the results. Because of small sample size, we were not able to stratify the analysis by age at evacuation or length of evacuation. If the evacuation effects vary strongly across these factors, our results may hide important patterns. However, additional data would need to be collected to address these issues. 
Table 7: Background characteristics of the analytic sample and of those who died or emigrated before 1971

\begin{tabular}{|c|c|c|c|c|}
\hline \multirow{3}{*}{ Characteristic } & \multirow{2}{*}{\multicolumn{2}{|c|}{$\begin{array}{c}\text { Analytic sample } \\
(n=66,615)\end{array}$}} & \multicolumn{2}{|c|}{$\begin{array}{c}\text { Died or emigrated } \\
\text { before } 1971\end{array}$} \\
\hline & & & & $=4,037)$ \\
\hline & $N$ & Mean $(\%)$ & $N$ & Mean $(\%)$ \\
\hline Women & 32,265 & 48.44 & 1,661 & 41.14 \\
\hline Men & 34,350 & 51.56 & 2,376 & 58.86 \\
\hline \multicolumn{5}{|l|}{ Evacuee status } \\
\hline Evacuated & 2,009 & 3.89 & 206 & 5.10 \\
\hline Not evacuated & 64,606 & 96.98 & 3,831 & 94.90 \\
\hline \multicolumn{5}{|l|}{$\begin{array}{l}\text { Socioeconomic status } \\
\text { in } 1939\end{array}$} \\
\hline Entrepreneur & 17,509 & 26.28 & 952 & 23.58 \\
\hline White collar worker & 6,390 & 9.60 & 389 & 9.63 \\
\hline Blue collar worker & 20,087 & 30.15 & 1,317 & 32.62 \\
\hline Assisting family member & 5,337 & 8.02 & 302 & 7.48 \\
\hline Unemployed or out of LF & 17,292 & 25.96 & 1,077 & 26.68 \\
\hline \multicolumn{5}{|l|}{ Parental education } \\
\hline Primary school or less & 61,790 & 92.76 & 3,732 & 92.44 \\
\hline Past primary school & 4,825 & 7.24 & 305 & 7.56 \\
\hline \multicolumn{5}{|l|}{ Number of children } \\
\hline in the family in 1940 & & 1.62 & & 1.41 \\
\hline One & 12,606 & 18.92 & 648 & 16.05 \\
\hline Two & 12,155 & 18.25 & 559 & 13.85 \\
\hline Three or more & 18,210 & 27.34 & 1003 & 24.84 \\
\hline \multicolumn{5}{|l|}{ Native language } \\
\hline Finnish & 62,516 & 93.85 & 3,581 & 88.70 \\
\hline Swedish & 4,099 & 6.15 & 456 & 11.30 \\
\hline
\end{tabular}

\subsection{Conclusions}

Separation from parents induced by external shocks, such as the onset of war in our case, is a more extreme event than other forms of family disruption, e.g., marriage breakdown, in the sense that evacuation to foster care involves changes to all aspects of family environment. Still, we find no consistent evidence of any causal effect of family disruption on family formation and reproductive behavior. 
There are many ways to reconcile our null results with the literature that finds associations between family instability and the child's subsequent family formation and reproductive behavior (e.g, Kiernan 1992; McLanahan and Bumpass 1988; McLeod 1991; Rostila and Saarela 2011). First, unobserved heterogeneity in some of the earlier studies may bias the reported associations. This interpretation is supported by our finding that in naïve OLS regressions family disruption appears to strongly predict later family formation and fertility behavior, but when unobserved heterogeneity is controlled for via sibling fixed effects approach, the effects vanish.

Second, the left-behind siblings who stayed with their biological parents throughout the war may have been adversly affected by the separation from their siblings. This may bias the evacuation estimates towards zero.

Third, it is possible that the context is critical for the effects. Much of the literature on family disruption and later family formation and fertility behavior comes from AngloSaxon countries (Kiernan 1992; McLanahan and Bumpass 1988; McLeod 1991). It is an important but difficult question as to whether the Finnish context might influence the impact of family disruption differently than what other contexts might. The decades during which the children we analyzed came of age were characterized by relatively high social mobility, in particular among the lower social classes (Bratsberg et al. 2007; Österbacka 2001). It is possible that a social context that provides high social mobility provides opportunities that attenuate the effects of family disruption. Further, recent studies by Saarela and Finnäs $(2009,2012)$ on other populations in Finland affected by the events of WWII, namely, war veterans and adults internally displaced from areas ceded to the Soviet Union in 1940, find no elevation in long-term mortality rates among the exposed groups compared to their unexposed counterparts.

Fourth, it is also possible that the impact of family disruption does not increase monotonically with how dramatic the event of disruption is. Most studies on family disruption focus on divorce or death of a parent. It is possible that the effect on the child of experiencing parental divorce or parental death is smaller than the war time evacuation to another country. Further research is needed to understand how the nature of family disruption influences the family formation trajectory of the child.

Despite these interpretational issues, our results strongly suggest that the identification of the effect of family disruption on later life outcomes is sensitive to the choice of research design. The lack of consistent evidence of any causal effect of family disruption on subsequent family formation and reproductive behavior that our results provide, relies on controlling for unobserved confounding by use of within-siblings design. By use of naïve regression adjusted means comparison the results look different. This observation suggests that some of the adverse outcomes documented in earlier literature could change if confounding was accounted for. 


\section{References}

Allsworth, J.E., Zierler, S., Lapane, K.L., Krieger, N., Hogan, J.W., and Harlow, B.L. (2004). Longitudinal study of the inception of perimenopause in relation to lifelong history of sexual or physical violence. Journal of Epidemiology and Community Health 58(11): 938-943. doi:10.1136/jech.2003.017160.

Amato, P.R. (2010). Research on Divorce: Continuing Trends and New Developments. Journal of Marriage and Family 72(3): 650-666. doi:10.1111/j.17413737.2010.00723.x.

Appel, C.W., Johansen, C., Deltour, I., Frederiksen, K., Hjalgrim, H., Dalton, S.O., Dencker, A., Dige, J., Bøge, P., Rix, B.A., Dyregrov, A., Engelbrekt, P., Helweg, E., Mikkelsen, O.A., Høybye, M.T., and Bidstrup, P.E. (2013) Early Parental Death and Risk of Hospitalization for Affective Disorder in Adulthood. Epidemiology 24(4): 608-615. doi:10.1097/EDE.0b013e3182915df8.

Belsky, J. (2008). War, trauma and children's development: observations from a modern evolutionary perspective.International Journal of Behavioral Development 32(4): 260-271. doi:10.1177/0165025408090969.

Belsky, J., Steinberg, L., and Draper, P. (1991). Childhood Experience, Interpersonal Development, and Reproductive Strategy: An Evolutionary Theory of Socialization. Child Development 62(4): 647-670. doi:10.2307/1131166.

Bharadwaj, P., Løken, K.W., and Neilson, C. (2013). Early Life Health Interventions and Academic Achievement. American Economic Review 103(5): 1862-91. doi:10.1257/aer.103.5.1862.

Bhrolcháin, M.N. (2001). 'Divorce Effects' and Causality in the Social Sciences. European Sociological Review 17(1): 33-57. doi:10.1093/esr/17.1.33.

Björklund, A. and Sundström, M. (2006). Parental Separation and Children's Educational Attainment: A Siblings Analysis on Swedish Register Data. Economica 73(292): 605624. doi:10.1111/j.1468-0335.2006.00529.x.

Black, S.E., Devereux, P.J., and Salvanes, K.G. (2005). The More the Merrier? The Effect of Family Size and Birth Order on Children's Education . Quarterly Journal of Economics 120(2): 669-700. doi:10.1093/qje/120.2.669.

Bound, J. and Solon, G. (1999). Double trouble: On the value of twins-based estimation of returns to schooling. Economics of Education Review 18(2): 169-182. doi:10.1016/S0272-7757(98)00048-X.

Bowlby, J. (1980). Attachment and Loss. New York, NY: Basic Books. 
Santavirta \& Myrskylä: Reproductive behavior following evacuation to foster care during World War II

Bratsberg, B., Røed, K., Raaum, O., Naylor, R., Jäntti, M., Eriksson, T., and Österbacka, E. (2007). Nonlinearities in Intergenerational Earnings Mobility: Consequences for Cross-Country Comparisons. Economic Journal 117(519): C72-C92. doi:10.1111/j.1468-0297.2007.02036.x.

Cameron C.A. and Miller D.L. (2015). A practitioner's guide to cluster-robust inference. Journal of Human Resources.

Corak, M. (2001). Death and Divorce: The Long-Term Consequences of Parental Loss on Adolescents. Journal of Labor Economics 19(3): 682-715. doi:10.1086/322078.

Del Bono, E., Ermisch, J., and Francesconi, M. (2012). Intrafamily Resource Allocations: A Dynamic Structural Model of Birth Weight. Journal of Labor Economics 30(3): 657-706. doi:10.1086/664831.

Duncan, G., Yeung, W.J., Brooks-Gunn, J., and Smith, J.R. (1998). How Much Does Childhood Poverty Affect the Life Chances of Children? American Sociological Review 63(3): 406-423. doi:10.2307/2657556.

Ermisch, J.F. and Francesconi, M. (2001). Family structure and children's achievements. Journal of Population Economics 14(2): 249-270. doi:10.1007/s001480000028.

Gennetian, L.A. (2005). One or two parents? Half or step siblings? The effect of family structure on young children's achievement. Journal of Population Economics 18(3): 415-436. doi:10.1007/s00148-004-0215-0.

Gilman, S.E., Kawachi, I., Fitzmaurice, G.M., and Buka, S.L. (2003). Family Disruption in Childhood and Risk of Adult Depression. American Journal of Psychiatry 160(5): 939-946. doi:10.1176/appi.ajp.160.5.939.

Hardy, R. and Kuh, D. (2005). Social and environmental conditions across the life course and age at menopause in a British birth cohort study. BJOG: An International Journal of Obstetrics \& Gynaecology 112(3): 346-354. doi:10.1111/j.14710528.2004.00348.x.

International Committee of the Red Cross. Central Tracing Agency and Protection Division (2004). Inter-Agency Guiding Principles on Unaccompanied and Separated Children. Geneva: International Committee of the Red Cross, Central Training Agency and Protection Division.

Kavén, P. (2010). Humanitaarisuuden varjossa: Poliittiset tekijät lastensiirroissa Ruotsiin sotiemme aikana ja niiden jälkeen. [Ph.D. Thesis]. Helsinki, Finland: University of Helsinki, Faculty of Arts, Dept. of Philosophy, History, Culture and Art Studies. (English summary available at: http://urn.fi/URN:ISBN:978-952-10-6722-8)

Kearney, M.S. and Levine, P.B. (2014). Income Inequality and Early Nonmarital Child- 
bearing. Journal of Human Resources 49(1): 1-31. doi:10.1353/jhr.2014.0001.

Kendler K.S., Sheth K., Gardner C.O., and Prescott C.A. (2002). Childhood parental loss and risk for first-onset of major depression and alcohol dependence: the time-decay of risk and sex differences. Psychological Medicine 32(7): 1187-1194. doi:10.1017/S0033291702006219.

Kiernan, K.E. (1992). The Impact of Family Disruption in Childhood on Transitions Made in Young Adult Life. Population Studies 46(2): 213-234. doi:10.1080/0032472031000146206.

Lang, K. and Zagorsky, J.L. (2001). Does Growing up with a Parent Absent Really Hurt? Journal of Human Resources 36(2): 253-273. doi:10.2307/3069659.

Lehtiranta, L. (1996). Matkalla Kodista Kotiin: Sotalapset Muistelevat. (On the Road from One Home to Another: Recollections by Child Evacuees). Vantaa: PohjolaNorden.

Lomu, J. (1974). Lastensiirtokomitea ja sen arkisto 1941-1949 (Engl. The Child Evacuation Comittee and its Archives 1941-1949). Publication Series of the National Archives, Finland, 441(5a).

Lundberg, S. and Plotnick, R.D. (1995). Adolescent Premarital Childbearing: Do Economic Incentives Matter? Journal of Labor Economics 13(2): 177-200. doi:10.1086/298372.

Lyngstad, T.H. and Prskawetz, A. (2010). Do siblings' fertility decisions influence each other? Demography 47(4): 923-934. doi:10.1007/BF03213733.

McCall, R.B. (1977). Childhood IQ's as Predictors of Adult Educational and Occupational Status. Science 197(4302): 482-483. doi:10.1126/science.197.4302.482.

McLanahan, S. and Bumpass, L. (1988). Intergenerational Consequences of Family Disruption. American Journal of Sociology 94(1): 130-152. doi:10.1086/228954.

McLanahan, S. and Sandefur, G. (1994). Growing up with a single parent, what hurts, what helps. Cambridge, MA: Harvard University Press.

McLeod, J.D. (1991). Childhood Parental Loss and Adult Depression. Journal of Health and Social Behavior 328§9: 205-220. doi:10.2307/2136804.

National Institute for Health and Welfare, Finland. Division for Social Protection. (2013). Child Welfare 2012 - Statistical Report. Official Statistics of Finland.

Österbacka, E. (2001). Family Background and Economic Status in Finland. Scandinavian Journal of Economics 103: 467-484. doi:10.1111/1467-9442.00255.

Pesonen, A.-K., Räikkönen, K., Heinonen, K., Kajantie, E., Forsén, T., and Eriksson, J.G. 
Santavirta \& Myrskylä: Reproductive behavior following evacuation to foster care during World War II

(2008). Reproductive traits following a parent-child separation trauma during childhood: A natural experiment during World War II. American Journal of Human Biology 20(3): 345-351. doi:10.1002/ajhb.20735.

Powers, D.A. (2005). Effects of family structure on the risk of first premarital birth in the presence of correlated unmeasured family effects. Social Science Research 34(3): 511-537. doi:10.1016/j.ssresearch.2004.04.007.

Rosenzweig, M. and Wolpin, K. (1995). Sisters, Siblings, and Mothers: The Effect of Teen-Age Childbearing on Birth Outcomes in a Dynamic Family Context. Econometrica 63(2): 303-326. doi:10.2307/2951628.

Rostila, M. and Saarela, J.M. (2011). Time Does Not Heal All Wounds: Mortality Following the Death of a Parent. Journal of Marriage and Family 73(1): 236-49. doi:10.1111/j.1741-3737.2010.00801.x.

Rostila, M, Saarela, J.M., and Kawachi, I. (2014). Birth Order and Suicide in Adulthood: Evidence From Swedish Population Data. American Journal of Epidemiology 179(12): 1450-1457. doi:10.1093/aje/kwu090.

Saarela, J.M. and Finnäs, F. (2009). Long-term Mortality of War Cohorts: The Case of Finland. European Journal of Population 28(1): 1-15. doi:10.1007/s10680-011-9246$\mathrm{x}$.

Saarela, J.M. and Finnäs, F. (2012). Forced migration and mortality in the very long term: Did perestroika affect death rates in Finland? Demography 46(3): 575-587. doi:10.1353/dem.0.0069.

Santavirta, N. and Santavirta, T. (2014). Child protection and adult depression: Evaluating the long-term consequences of evacuating children to foster care during World War II. Health Economics, 23(3): 253-278. doi:10.1002/hec.2913.

Schaffer, M.E. and Stillman, S. (2010). xtoverid: Stata module to calculate tests of overidentifying restrictions after xtreg, xtivreg, xtivreg2 and xthtaylor. http://ideas.repec.org/c/boc/bocode/s456779.html

UNHCR. (2012). Global trends: Displacement: The New $21^{\text {th }}$ Century Challenge. Available at: http://www.unhcr.org/51bacb0f9.html. Accessed October 25, 2013.

U.S. Department of Health and Human Services, Administration for Children and Families, Administration on Children, Youth and Families. (2013). The AFCARS Report: Preliminary FY 2012 Estimates as of November 2013. Washington, DC: US Government Printing Office.

Wooldridge, J.M. (2010). Econometric Analysis of Cross Section and Panel Data. Cambridge, MA: MIT Press. 


\section{Appendix}

\section{The evacuation policy ${ }^{7}$}

\section{Historical background}

Finland fought two wars against the Soviet Union between 1939 and 1944 during World War II. Despite Finnish collaboration with the Axis Powers during World War II, Finland's resistance against Stalin's Red Army received moral support from many Western countries. Food and material aid was received from international organizations and credit was granted by several countries.

In June 1941, a plan for a large scale operation of evacuating Finnish children to Sweden emerged. A nationwide volunteer organization was established in Sweden to attend to the placement of the children, and a large scale network of volunteer foster families was mobilized. ${ }^{8}$ In Finland, the evacuations were organized by a nationwide organization under the auspices of the Ministry of Social Affairs, relying on the nationwide civilian service logistic infrastructure, including local offices and staff. These two organizations designed the evacuation scheme and carried out the major part of the evacuations and placements in foster families made between 1941 and $1945 .{ }^{9}$

The official motives for a mass evacuation of children were, as stated by the Ministry of Social Affairs, that children who were particularly exposed to the various adversities of war should be given a better rearing environment. At first, each Finnish county was granted a quota of evacuees, but restricting the selection of participants to the stated quotas proved difficult as fear for air raids spread among the urban population and food became scarce. The original eligibility criteria were the following: 1 . children of displaced Karelian families; ${ }^{10} 2$. children whose fathers were wounded in battle; 3 . children who had lost their home in bombings; 4. children whose father's had died in war or who had lost their parents in bombings. In January 1942, the criteria were expanded to include children from large families, children whose mothers were working full time, and also children who resided in towns that were potential targets for air raids. This latter criterion applied, in practice, to most eastern and southern towns of Finland, and therefore

\footnotetext{
${ }^{7}$ The chief part of the documents that this section is based on are available in the Files for The Child Evacuation Scheme during World War II at The National Archives of Finland (NAF). When not specifically mentioned, I refer to Lomu (1974), who constructs a detailed report on the evacuation scheme based on the documents of NAF.

${ }^{8}$ No financial compensation for accommodating Finnish children was ever promised to the Swedish families. In other words, the accommodating of evacuees was based purely on philanthropic grounds.

${ }^{9}$ Most evacuations were made in the winter between 1941 and 1942 and in 1944.

${ }^{10}$ Being the border region between Finland and the Soviet Union, Karelia was the region most adversely affected by the war. Roughly 400,000 people, virtually the whole Karelian population, had already been displaced to other regions of Finland in 1940, as a consequence of the Moscow Peace Treaty between the Soviet Union and Finland, which granted Karelia to the Soviet Union. Figure A presents the ceded part of Karelia on a map of Finland.
} 
most children from these areas were considered eligible. At first the objective was to send preschoolers. A strict age criterion however was not applied in practice, due, for instance, to the difficulty choose between siblings of various age. Statistics show that roughly half of the children were past school starting age by the time of evacuation.

In total 48,628 children were evacuated to Sweden through the described evacuation scheme and roughly an additional 20,000 children were sent to Sweden independent from the official evacuation program, to relatives and friends. In total, it is estimated that roughly 65,000 children spent from a couple of months up to five years (on average two years) in foster care in Swedish families during World War II. The total number of evacuees equals the size of one Finnish cohort during the 1930s.

\section{The avacuation from Finland to Sweden}

A large organization, called the Evacuation Committee, was set up on the foundations of the existing war time civilian support organization to conduct the evacuations, with the help from numerous volunteers. ${ }^{11}$ The organization made itself known through nationwide broadcasting and advertising in local newspapers. Headquarters were established in Helsinki, employing a large administrative staff. The Evacuation Committee set up and funded regional subsidiary offices that were largely run by volunteers, such as local nurses. After the evacuations began, in September 1941, the county offices were converted into evacuation centers handling the selection process, transportation arrangements, documentation, accounting, correspondence between the evacuees and their families, and advertising of the evacuation scheme in the local media. Absorption centers were set up near the ports of Turku and Vaasa, from whence the evacuees were sent to Sweden by boat and in the border towns of Tornio and Kemi, from where the evacuees crossed the border by railway. All travel expenses were covered by the Evacuation Committee.

Parents who had learned about the evacuation program through mass media or local authorities first filed an application to the local evacuation office. In the application the parents had to account for the reasons for applying to the program and list their status on each of the eligibility criteria. Families with more than one child could opt for including all their children in the application or decide to evacuate only some of their children (this was quite a usual strategy in large families in which malnutrition was a common reason for participation). Even though the family background (eligibility criteria) of each evacuee was well documented through the screening process, neither the child evacuee registry nor historical accounts has much to say about selective behavior within families that evacuated only some of their children; the actual evacuation decision was considered to be a family matter (Kavén 2010). When the application was approved, a health check at the local hospital followed and an identification document including a photograph was

\footnotetext{
${ }^{11}$ The Civilian Service of Finland contributed with an already existing network of volunteers. This organization was founded in 1939 for the purpose of distributing aid packages received from foreign oragnizations.
} 
issued. The documents were sent to the local evacuation office where the child's file was put into a queue awaiting information on the region's quota for the following evacuation round. As soon as the headquarters of the organization gave information of each region's quota for the next round, the county office gathered the children - according to the ordered date of application approval - to the nearest railway station, from whence they were sent to the absorption centers. The children were not allowed to carry any money, and their ration cards (most grocery products were rationed in Finland during the war) needed to be handed in before departure. ${ }^{12}$ The children brought with them a franked envelope, which the foster parents that would be assigned in Sweden were urged to post to the Finnish county office with notification of the child's arrival and their name and address, to enable correspondence between the biological parents and their child. Upon arrival at the absorption center, a brief health check was conducted and information on the children was entered into an evacuee register. Each child was assigned a running number according to arrival order and given an identification placard to carry around her neck.

Based on the above description of the evacuation, it is plausible that the evacuation created randomness in the order in which the children were transported to Sweden. The strongest argument in favor of random order of evacuation with respect to any background characteristics would be that the children were processed according to a running number upon the arrival at the absorption centers and boarded the vehicle of transportation accordingly.

\section{The placement to foster families in Sweden}

In Sweden, the structure of the Placement Committee was virtually a mirror image of the Evacuation Committee on the Finnish side. Its main office was located in Stockholm and each county had its own local organization led by an authorized representative who was in charge of the placement of the children into families. In practice, large local volunteer organizations conducted the major part of the placement operations, and the provincial offices handled registries of children and other administrative issues. Quarantine centers were established in geographically strategic Swedish towns, usually the capital of the county.

At first, as the contingents arrived in Swedish territory, they were taken to sanitary centers, which were located in the near proximity of the arrival port or station (Stockholm, Umeå and Haparanda), where brief health checks were conducted. At the sanitary centers, the contingents were split into smaller groups which were placed in quarantine centers for a week. They went through careful health checks before being assigned a county of destination and eventually a foster family, to confirm that they were not carrying any contagious diseases. Although medical issues were of first priority, much weight was put on nutrition and inventory of the children's luggage. Clothes were provided for poorly

12 This made any form of bribing of the officials difficult for the children. 
equipped children, and all children were washed thoroughly. When leaving the quarantine centers, the children were separated into smaller groups and transported via the county offices, where the group would be re-shuffled into smaller units, to their final destinations.

Little is documented about the final stage of the evacuation, that is, the placement in foster families, and thus one is principally referred to anecdotal evidence as recalled or retold by the evacuees. ${ }^{13}$ Regarding the different stages of the journey until the local Swedish provincial offices, anecdotal evidence conforms unusually well with the information in official documents. The final stage of the trip to the eventual placement seems to have been completed in three different ways: 1 . when several children arrived at the same time in a community, the distribution of children to foster families would take place at some temporary lodging, e.g. the local parish house or school premises, according to a first-come first-served process, ${ }^{14} 2$. in sparsely populated areas, or in areas where only one family was awaiting a child, the assigned family would receive the child on a bus stop or train station without means to affect the choice of child, 3. in some cases the local ombudsman for the placement committee, often the local priest or school principal, assigned the children to families at their arrival on the train or bus station.

The description of the events during the journey to the final destination suggests that the children were processed anonymously according to the information provided on an identification placard hanging around their neck, i.e., an assigned running number, name and gender, and sorted randomly at several stages of the journey. By the time the children reached the last leg of their transportation, the inequalities in clothing, cleanliness, and nutrition are supposed to have been leveled out, and thus to have made any inference of social background based on appearance difficult.

\footnotetext{
${ }^{13}$ We make use of a compilation of 135 short stories of recollections by the evacuees edited by Leila Lehtiranta (1996).

${ }^{14}$ Pirkko Bergman, a one time child evacuee, recalls "we (the children) were taken to a room and were told to sit on chairs with the identification plates visibly displayed. A group of people rushed in and among the first ones was a tall man who examined me, wrote something indicating 'reserved' on the parcel I was carrying and continued to examine others. Others showed interest in me but noticed the reservation sign on the package. The tall man, who turned out to be the priest of the village of Åsunden, Gösta Rosen, returned to pick me up together with another child, whom, I found out upon our arrival in the village, he had chosen for himself, I was assigned to a neighbouring family" (Lehtiranta 1996).
} 
Table A-1: $\quad$ Probit estimates: Child evacuation and marriage patterns

\begin{tabular}{lcccc}
\hline & \multicolumn{2}{c}{ Ever married } & \multicolumn{2}{c}{ Divorced } \\
& Women & Men & Women & Men \\
\hline Evacuated & 0.009 & 0.002 & 0.082 & 0.006 \\
& $(0.009)$ & $(0.010)$ & $(0.015)$ & $(0.012)$ \\
Parental education, & & & & \\
(Past primary school=1) & -0.007 & $0.028^{* * *}$ & 0.034 & 0.005 \\
& $(0.007)$ & $(0.066)$ & $(0.011)$ & $(0.009)$ \\
SES in 1939 & & & & \\
White collar & $-0.015^{* *}$ & $0.049^{* * *}$ & 0.024 & $0.039^{* * *}$ \\
& $(0.007)$ & $(0.005)$ & $(0.010)$ & $(0.010)$ \\
Blue collar & $0.019^{* * *}$ & $0.026^{* * *}$ & 0.050 & $0.055^{* * *}$ \\
& $(0.004)$ & $(0.004)$ & $(0.007)$ & $(0.006)$ \\
Assisting family member & $<0.001$ & -0.010 & 0.005 & -0.004 \\
& $(0.006)$ & $(0.007)$ & $(0.009)$ & $(0.009)$ \\
Unemployed or out of labor force & $0.009^{* *}$ & $0.019^{* * *}$ & 0.046 & $0.049^{* * *}$ \\
& $(0.004)$ & $(0.004)$ & $(0.007)$ & $(0.007)$ \\
Native language, (Swedish=1) & $0.024^{* * *}$ & 0.004 & -0.030 & $-0.036^{* * *}$ \\
& $(0.007)$ & $(0.009)$ & $(0.010)$ & $(0.009)$ \\
Number of children in & & & & \\
the family in 1940 & -0.003 & $-0.007^{* * *}$ & -0.002 & 0.001 \\
& $(0.002)$ & $(0.002)$ & $(0.003)$ & $(0.002)$ \\
Observations & 32,265 & 34,350 & 29,407 & 30,840 \\
\hline
\end{tabular}

Notes: Marginal effects of probit estimates for evacuee status evaluated at the sample mean of the explanatory variables. Standard errors (in parentheses) are clustered at family level. All specifications also include 12 categorical variables for birth order, 20 categorical variables for residence municipality in 1939 and 11 categorical variables for birth cohort. Age at first childbirth and inter-birth interval are measured in days.

Table A-2: Differences in evacuation status among siblings according to sibship size

\begin{tabular}{lrrrrr}
\hline & $\begin{array}{c}\text { All } \\
(n=43,665 \\
\text { pairs })\end{array}$ & $\begin{array}{c}\text { Two siblings } \\
(n=9,957 \\
\text { pairs })\end{array}$ & $\begin{array}{c}\text { Three siblings } \\
(n=13,590 \\
\text { pairs })\end{array}$ & $\begin{array}{c}\text { Four siblings } \\
(n=10,806 \\
\text { pairs })\end{array}$ & $\begin{array}{c}\text { Five or more } \\
\text { siblings }(n= \\
9,346 \text { pairs })\end{array}$ \\
\hline Bvacuee status & 41,790 & 9,482 & 12,932 & 10,341 & 8,969 \\
Evac. vs. non-evac. & 1,321 & 295 & 458 & 348 & 220 \\
Evac. vs. evac. & 554 & 180 & 200 & 117 & 57 \\
\hline
\end{tabular}


Santavirta \& Myrskylä: Reproductive behavior following evacuation to foster care during World War II

Table 6: $\quad$ Reproductive traits and marriage patterns according to child-evacuee status during WW II - within-sibling analyses

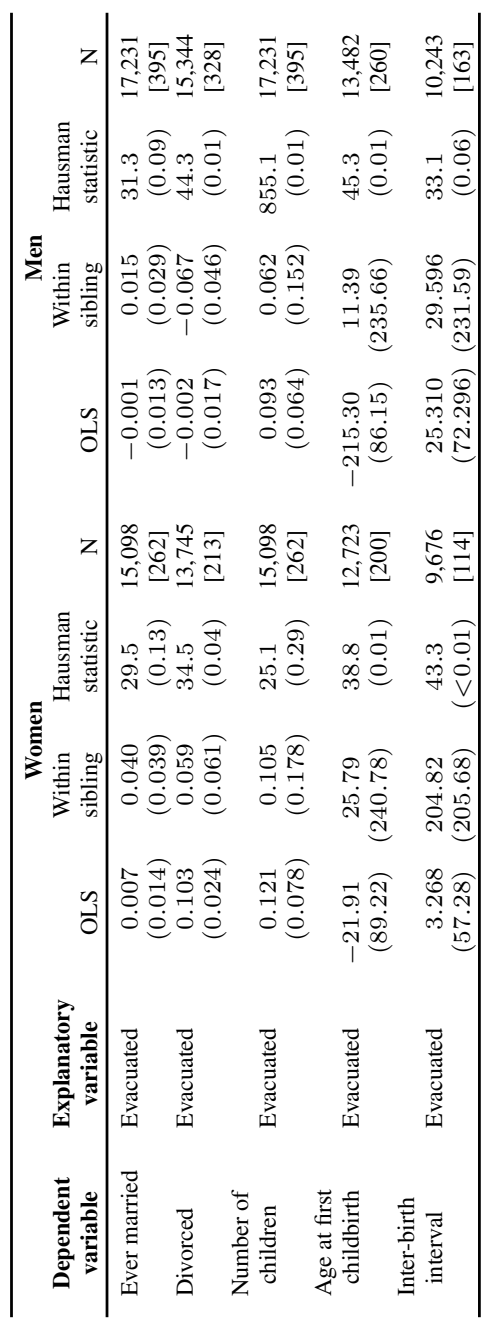

Notes: OLS estimates and within-sibling estimates for evacuee status. Standard errors (in parentheses) are clustered at family level. The OLS analysis adjusts for the same family background covariates as in Tables 4 and 5 while all family-specific covariates cancel out in the within-sibling analysis. All models adjust for birth order and year of birth. Age at first childbirth and inter-birth interval are measured in days. The Hausman test reports the F-statistic and p-value. Under the null hypothesis, OLS is consistent. The number of sibling pairs discordant for evacuee status are reported in square brackets. 